\title{
Association between Anthropometric indices and Cardiometabolic Risk Factors among Women with Primary Infertility
}

\section{Ernest Opoku Antwi ( $\square$ antwiernest@yahoo.com )}

Garden City University College, Department of Nursing, Kenyasi, Kumasi

\section{Vivian Baah}

Garden City University College, Department of Nursing, Kenyasi, Kumasi

\section{Research Article}

Keywords: cardiometabolic risk factors, anthropometric indices, primary infertility

Posted Date: September 16th, 2020

DOI: https://doi.org/10.21203/rs.3.rs-77331/v1

License: (c) (i) This work is licensed under a Creative Commons Attribution 4.0 International License. Read Full License 


\section{Abstract}

Background: Cardiometabolic risk factors are commonly associated with women with infertility. The study evaluated the association between anthropometric indices and cardiometabolic risk factors in women with primary infertility.

Methods: Two-hundred and sixteen (216) women with primary infertility underwent simple anthropometric measurement including waist circumference (WC), waist-to-height ratio (WHtR), body mass index (BMI), body adiposity index (BAI) and abdominal volume index (AVI). Blood pressure was assessed using an automated $\mathrm{BP}$ monitor and fasting blood samples were collected. Cardiometabolic risk factors were defined according to the NCEPATP III criteria. Receiver Operating Characteristic (ROC) curve and logistic regression analyses were used to evaluate associations

Results: The mean age of the study participants was 30.3 years and the median duration of infertility was 3.0 (2.0-4.0 interquartile range). The prevalence of hypertension was $22.2 \%$. Metabolic syndrome, hyperglycemia, and

dyslipidemia were presents among $23.1 \%, 32.4 \%$, and $48.1 \%$, respectively. BMl (between $25.8 \mathrm{Kg} / \mathrm{m}^{2}$ and $28.0 \mathrm{Kg} / \mathrm{m}^{2}$ ), strongly predicted hyperglycemia, MetS, and dyslipidemia. Additionally, the range of optimal cut-off values of central obesity indices including WC $(84.0 \mathrm{~cm}$ to $90.0 \mathrm{~cm})$, WHR $(0.85-0.89 \mathrm{~cm} / \mathrm{cm})$, WHtR $(0.52-0.61 \mathrm{~cm} / \mathrm{cm})$ and AVI $(14.3$ to 16.5) better predicted hyperglycaemia, MetS and dyslipidaemia. Only BMI and BAI were significant predictors of hypertension.

Conclusion: Cardiometabolic risk factors including hypertension, hyperglycemia, dyslipidemia and MetS are high among women with primary infertility. BMI proved superior in predicting cardiometabolic risk factors among primary infertile women.

\section{Introduction}

Infertility is a recognized global problem, affecting on average $8 \%$ to $12 \%$ of couples worldwide [1]. According to studies within the African continent, as high as 30.0\% prevalence of infertility among couples has been reported [2-4]. In Ghana, the prevalence rate of infertility is $11.8 \%$ among women and $15.8 \%$ among men [5]. According to the reports of Tabong and Adongo [6], infertility affects the challenge of social stigmatization denied membership in the ancestral world and family stress. Thus, women with subfertility may suffer from stress, depression, and anxiety, which has a contributing role in cardiovascular disease (CVD) [7]. Apart from the social effects of infertility, it has been associated with disturbances in glucose and lipid metabolism. A study by Verit et al., [8] showed that women with unexplained infertility have an atherogenic lipid profile and elevated high-sensitivity C-reactive protein levels. Infertility may share some common pathways with CVD according to a report by Parikh et al., [9]. Oxidative stress is common in infertile patients with conditions such as endometriosis, polycystic ovarian syndrome (PCOS), obesity, and unexplained infertility, which exaggerate the risk of cardio-metabolic abnormalities [10].

The relationship between obesity and reproductive functions has been known for many years [11, 12]. Obesity in recent years has been reportedly high among women with fertility issues [13]. Obesity complicates the treatment of anovulatory infertility and require a higher dosage of gonadotropin, respond poorly to ovarian stimulation, and have a higher risk of miscarriage $[14,15]$. The obese women with infertility also have an exaggerated risk of developing worst cardiovascular outcomes due to interrelated mechanisms of androgen effect and long term management $[8,16]$. Infertile patients with $\mathrm{BMI}>24 \mathrm{~kg} / \mathrm{m}^{2}$ has been shown to have higher systolic pressure and post-insulinemia levels in comparison with patients with normal BMI [17]. 
Several studies have evaluated the link between adiposity indices and cardiometabolic risk [18, 19], but the criterion of these indices for identifying cardiometabolic risk factors among infertile women is less explored. Also, sensitive and specific techniques including dual-energy X-ray absorptiometry (DXA), computed tomography (CT) and magnetic resonance imaging (MRI), for assessing body compositions is less accessible and expensive [20,21]. Thus, inexpensive measurements of adiposity with equivalent sensitivity for predicting MetS and its components merit attention and would provide important practical applications among infertile women. This study, therefore, evaluated the use of simple anthropometric indices, which has been validated in literature as an index of adiposity $[20,22,23]$ for predicting cardiometabolic risk factors among infertile women in a Ghanaian population.

\section{Methods}

\section{Study Design/setting}

A cross-sectional study was carried out at the Manhyia Government Hospital from September 2018 to March 2019.

\section{Target Population}

All patients visiting the hospital for infertility issues were included as a sample. Sub-fertile or infertile women above 18 years who were proved psychologically, physically and socially fit after an investigation by the gynaecologist were selected to partake in the study. Women presenting with infectious conditions such as human immunodeficiency virus (HIV), Hepatitis B and C, and tuberculosis were excluded from the study. Moreover, patients on any kind of hormone treatment or treatment with antihypertensive, antidiabetic and statins were excluded from the study. Primary infertility was defined as couples that had never conceived despite exposure to the risk of pregnancy for 1 year.

\section{Sample Size}

Using a proportionate ratio of infertility among women in Ghana to be $11.8 \%$ [5], at a confidence interval of $95 \%$, with $5 \%$ margin of error, the minimum required sample size for the study was 160 using the Cochrane formulae [24]. However, to adjust for a non-response rate of $25.0 \%$ and ensure high statistical power, a total of 216 samples were used.

\section{Blood Pressure Measurement}

Participants were asked to complete a self-administered questionnaire which asked about their age, and years of infertility. Aetiology of infertility was extracted from their folders. Measurements of blood pressure were measured with the subject being in the seated position using an automated BP monitor (Omron HEM-5001, Kyoto, Japan) from the subject's right arm. Three readings were recorded 3 to 5 minutes apart and the average of two closest systolic blood pressure (SBP) and diastolic blood pressure (DBP) readings were taken as the final reading.

\section{Anthropometric measurements}

Weight of each participant was measured using a platform electronic scale to the nearest $0.1 \mathrm{~kg}$. Waist circumference (WC) and hip circumference (HP) were measured using a non-extensible but flexible tape measure at the point of the umbilicus and the maximal gluteal position, respectively. Portable height-rod stadiometer was used for body height; the subject stood straight, with feet placed together and flat on the ground.

\section{Derived Anthropometric Indices}


BMI was calculated as body weight in kilograms divided by height in meters squared $(\mathrm{kg} / \mathrm{m} 2)$. Waist-to-hip ratio and waist-to-height ratio were estimated from the ratio of the waist $(\mathrm{cm})$ to hip $(\mathrm{cm})$ and waist $(\mathrm{cm})$ to height $(\mathrm{cm})$, respectively. Other indices like abdominal volume index (AVI) and body adiposity index (BAl) were calculated using the formulae below:

[25]

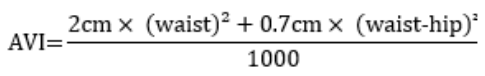

[26]

$$
\mathrm{BAI}=\frac{\text { hip circumference }(\mathrm{cm})}{\text { height }^{1.5}}-18
$$

\section{Sample Collection and Analysis}

Five millilitres $(\mathrm{ml})$ of fasting venous blood sample was drawn from the subject using standard venipuncture techniques. Two $\mathrm{ml}$ blood was dispensed into vacutainers containing sodium fluoride for estimation of plasma glucose (FBS). The remaining three $\mathrm{ml}$ was collected into serum separator tubes. Serum separated after clotting was used for routine biochemical analysis of triglycerides (TG), high-density lipoprotein cholesterol (HDL-C), total cholesterol (TC) and low-density lipoprotein cholesterol (LDL-C). All biochemical analysis was done using BTß 3000 Random Access Chemistry System (Elan Diagnostic Systems, USA).

\section{Definition of clinical characteristics}

Mets were defined according to the National Cholesterol Education Program Adult Treatment Panel III recommendation [27]. This criterion is based on the presence of at least three of the following five risk factors: (1) WC $\geq 88 \mathrm{~cm}$; (2) serum TG $\geq 1.7 \mathrm{mmol} / \mathrm{L}$; (3) HDL-C <1.30 mmol/L; (4) systolic and/or diastolic blood pressure $\geq 130$ or $85 \mathrm{~mm} \mathrm{Hg}$, respectively; and (5) fasting plasma glucose (FBS) $>6.1 \mathrm{mmol} / \mathrm{L}$. Since WC was used in the evaluation of MetS and cardiovascular risk a definition excluding WC criteria was used. Hence, MetS-adjusted criteria were determined as at least three of the four instead of five risk factors [28]. Subjects with one or more of the following results were considered to be dyslipidemia: TC $\geq 6.22 \mathrm{mmol} / \mathrm{L}, \mathrm{TG} \geq 2 \cdot 26 \mathrm{mmol} / \mathrm{L}, \mathrm{LDL}-\mathrm{C} \geq 4 \cdot 14 \mathrm{mmol} / \mathrm{L}$ or HDL-C $<1.03 \mathrm{mmol} / \mathrm{L}$ [27]. Hypertension was defined as either a systolic blood pressure of $\geq 140 \mathrm{mmHg}$ and/or diastolic blood pressure of $\geq 90 \mathrm{~mm} \mathrm{Hg}$.

\section{Statistical analysis}

Normal distribution of data was examined using the Kolmogorov-Smirnov test. Categorical data were expressed as frequencies and chi-square analyses were performed for comparing categorical variables. Pearson correlation analysis was performed to examine the relationship between anthropometric variables and cardiometabolic risk factors. The predictive ability of adiposity indices for cardiometabolic risk factors was assessed using the highest combination of sensitivity and specificity from Receiver operative characteristics (ROC) curve analysis, Cohen's kappa analysis and logistic regression analysis. Covariates used in the multivariate regression analysis are shown in Supplementary Table 3. The analysis was conducted using the Statistical Package for Social Sciences (SPSS 25.0) and $p$-value $<0.05$ was considered statistically significant.

\section{Results}

The mean age of the study subjects was $30.3( \pm 5.7 \mathrm{SD})$ and the median duration of infertility was 3.0 (2.0 to 4.0 interquartile range). Respondents with tubal factors as the cause of infertility were most 48 (22.2\%), followed by 
malefactors $36(16.7 \%)$, other causes 34 (15.7\%), hyperprolactinemia 30 (13.9\%), unexplained causes 28 (13.0\%) and polycystic ovarian syndrome $24(11.1 \%)$. The mean BMI was $28.6 \mathrm{Kg} / \mathrm{m}^{2}$. The means of central obesity measures were respectively, $88.6 \mathrm{~cm}, 0.87$ and 0.56 for WC, WHR, and WHtR [Supplementary Table 1].

Average BMI was significantly higher among with PCOS, Male factor and other causes of infertility compared women with unexplained causes of infertility ( $p$-value $=0.041$ ). Also, mean BAI was significantly lower among women with PCOS associated infertility compared with others with other causes ( $p$-value $=0.007$ ). Although not statistically significant ( $p$-value $=0.070$ ), the mean fasting blood glucose level was high for women with Male factor $(6.4 \mathrm{mmol} / \mathrm{L})$ and PCOS (6.5 mmol/L) associated infertility. Total cholesterol levels were significantly higher for Male factor (6.9 $\mathrm{mmol} / \mathrm{L})$ and PCOS $(6.7 \mathrm{mmol} / \mathrm{L})$ associated infertility, compared with others ( $\mathrm{p}$-value $<0.0001)$. Compared with Male factor and PCOS associated infertility ( $p$-value $<0.05)$, the levels of Triglycerides and LDL-C was lower for women with uterine and unexplained causes of infertility. Systolic blood pressure was significantly higher among women with male factor $(131.8 \mathrm{mmHg})$, unexplained $(131.5 \mathrm{mmHg})$ and other $(132.6 \mathrm{mmHg})$ cause of infertility. The prevalence of hypertension was higher among women with other causes of infertility 14/34 (41.2\%) and male factor 14/36 (38.9\%). Also, hyperglycemia was high among male factor 18/36 (50.0\%), PCOS 10/24 (41.7\%), other cause 14/34 (41.2\%) and tubal factor 16/48 (33.3\%) associated infertile women. The highest prevalence of dyslipidemia was observed among women with Male factor associated infertile women 26/36 (72.2\%), followed by PCOS 16/24 (66.7\%) and tubal factor 22/48 (45.8\%). No prevalence of MetS was observed among women with unexplained causes of infertility [Table 1]

\section{Table 1: Characteristics of the study participants stratified by causes of infertility}




\begin{tabular}{|c|c|c|c|c|c|c|c|c|}
\hline Variables & $\begin{array}{l}\text { Hyper- } \\
\text { prolactinemia } \\
(\mathrm{N}=30)\end{array}$ & $\begin{array}{l}\text { Tubal } \\
\text { factor } \\
(\mathrm{N}=48)\end{array}$ & $\begin{array}{l}\text { Male } \\
\text { factor } \\
(\mathrm{N}=36)\end{array}$ & $\begin{array}{l}\text { PCOS } \\
(\mathrm{N}=24)\end{array}$ & $\begin{array}{l}\text { Uterine } \\
\text { causes } \\
(\mathrm{N}=16)\end{array}$ & $\begin{array}{l}\text { Unexplained } \\
\text { Causes } \\
(\mathrm{N}=28)\end{array}$ & $\begin{array}{l}\text { Other } \\
\text { causes } \\
(\mathrm{N}=34)\end{array}$ & P-value \\
\hline \multicolumn{9}{|l|}{$\begin{array}{l}\text { Anthropometric } \\
\text { indices }\end{array}$} \\
\hline $\begin{array}{l}\text { Body mass } \\
\text { index }\left(\mathrm{Kg} / \mathrm{m}^{2}\right)\end{array}$ & $28.8(0.80)$ & $\begin{array}{l}28.5 \\
(0.91)\end{array}$ & $\begin{array}{l}29.7 \\
(0.91)\end{array}$ & $\begin{array}{l}29.8 \\
(1.12)\end{array}$ & $\begin{array}{l}27.5 \\
(1.13)\end{array}$ & $25.9(0.77)$ & $\begin{array}{l}29.6 \\
(0.65)\end{array}$ & 0.041 \\
\hline $\begin{array}{l}\text { Waist } \\
\text { Circumference } \\
\text { (cm) }\end{array}$ & $84.9(1.45)$ & $\begin{array}{l}90.5 \\
(2.14)\end{array}$ & $\begin{array}{l}88.1 \\
(1.36)\end{array}$ & $\begin{array}{l}88.6 \\
(2.1)\end{array}$ & $\begin{array}{l}86.4 \\
(2.48)\end{array}$ & $88.1(2.44)$ & $\begin{array}{l}90.8 \\
(1.57)\end{array}$ & 0.342 \\
\hline $\begin{array}{l}\text { Waist-to-hip } \\
\text { ratio }\end{array}$ & $0.85(0.007)$ & $\begin{array}{l}0.88 \\
(0.016)\end{array}$ & $\begin{array}{l}0.87 \\
(0.073)\end{array}$ & $\begin{array}{l}0.89 \\
(0.010)\end{array}$ & $\begin{array}{l}0.88 \\
(0.023)\end{array}$ & $0.86(0.014)$ & $\begin{array}{l}0.87 \\
(0.007)\end{array}$ & 0.422 \\
\hline $\begin{array}{l}\text { Waist-to-height } \\
\text { ratio) }\end{array}$ & $0.54(0.009)$ & $\begin{array}{l}0.56 \\
(0.014)\end{array}$ & $\begin{array}{l}0.56 \\
(0.007)\end{array}$ & $\begin{array}{l}0.54 \\
(0.013)\end{array}$ & $\begin{array}{l}0.54 \\
(0.013)\end{array}$ & $0.55(0.014)$ & $\begin{array}{l}0.57 \\
(0.009)\end{array}$ & 0.372 \\
\hline $\begin{array}{l}\text { Body adiposity } \\
\text { index }\end{array}$ & $31.8(0.97)$ & $\begin{array}{l}32.1 \\
(0.87)\end{array}$ & $\begin{array}{l}33.5 \\
(0.79)\end{array}$ & $\begin{array}{l}29.2 \\
(0.80)\end{array}$ & $\begin{array}{l}31.0 \\
(0.92)\end{array}$ & $32.8(0.96)$ & $\begin{array}{l}34.3 \\
(0.78)\end{array}$ & 0.007 \\
\hline $\begin{array}{l}\text { Abdominal } \\
\text { volume index }\end{array}$ & $14.7(0.51)$ & $\begin{array}{l}17.0 \\
(0.79)\end{array}$ & $\begin{array}{l}15.8 \\
(0.47)\end{array}$ & $\begin{array}{l}16.0 \\
(0.72)\end{array}$ & $\begin{array}{l}15.3 \\
(0.90)\end{array}$ & $16.0(0.91)$ & $\begin{array}{l}16.8 \\
(0.58)\end{array}$ & 0.243 \\
\hline \multicolumn{9}{|l|}{$\begin{array}{l}\text { Biochemical } \\
\text { parameters }\end{array}$} \\
\hline $\begin{array}{l}\text { Fasting plasma } \\
\text { sugar }\end{array}$ & $5.3(0.38)$ & $\begin{array}{l}5.7 \\
(0.37)\end{array}$ & $\begin{array}{l}6.4 \\
(0.42)\end{array}$ & $\begin{array}{l}6.5 \\
(0.63)\end{array}$ & $\begin{array}{l}5.0 \\
(0.25)\end{array}$ & $5.1(0.22)$ & $\begin{array}{l}5.8 \\
(0.33)\end{array}$ & 0.070 \\
\hline $\begin{array}{l}\text { Total } \\
\text { Cholesterol }\end{array}$ & $5.3(0.27)$ & $\begin{array}{l}5.8 \\
(0.23)\end{array}$ & $\begin{array}{l}6.9 \\
(0.51)\end{array}$ & $\begin{array}{l}6.7 \\
(0.58)\end{array}$ & $\begin{array}{l}4.7 \\
(0.17)\end{array}$ & $4.7(0.24)$ & $\begin{array}{l}5.3 \\
(0.22)\end{array}$ & $<0.0001$ \\
\hline Triglyceride & $1.6(0.19)$ & $\begin{array}{l}1.3 \\
(0.08)\end{array}$ & $\begin{array}{l}1.6 \\
(0.21)\end{array}$ & $\begin{array}{l}1.7 \\
(0.18)\end{array}$ & $\begin{array}{l}1.2 \\
(0.13)\end{array}$ & $1.0(0.06)$ & $\begin{array}{l}1.5 \\
(0.10)\end{array}$ & 0.028 \\
\hline HDL-C & $1.48(0.10)$ & $\begin{array}{l}1.59 \\
(0.08)\end{array}$ & $\begin{array}{l}1.57 \\
(0.07)\end{array}$ & $\begin{array}{l}1.85 \\
(0.17)\end{array}$ & $\begin{array}{l}1.58 \\
(0.15)\end{array}$ & $1.58(0.11)$ & $\begin{array}{l}1.60 \\
(0.14)\end{array}$ & 0.556 \\
\hline LDL-C & $3.45(0.27)$ & $\begin{array}{l}3.91 \\
(0.24)\end{array}$ & $\begin{array}{l}5.04 \\
(0.48)\end{array}$ & $\begin{array}{l}4.46 \\
(0.44)\end{array}$ & $\begin{array}{l}2.85 \\
(0.18)\end{array}$ & $2.88(0.23)$ & $\begin{array}{l}3.38 \\
(0.17)\end{array}$ & $<0.0001$ \\
\hline \multicolumn{9}{|l|}{$\begin{array}{l}\text { Blood pressure } \\
\text { indices }\end{array}$} \\
\hline $\mathrm{SBP}(\mathrm{mmHg})$ & $129.0(2.80)$ & $\begin{array}{l}126.7 \\
(1.52)\end{array}$ & $\begin{array}{l}131.8 \\
(2.52)\end{array}$ & $\begin{array}{l}122.6 \\
(2.22)\end{array}$ & $\begin{array}{l}126.0 \\
(3.64)\end{array}$ & $131.5(1.68)$ & $\begin{array}{l}132.6 \\
(2.57)\end{array}$ & 0.040 \\
\hline $\mathrm{DBP}(\mathrm{mmHg})$ & $77.7(1.60)$ & $\begin{array}{l}79.0 \\
(1.13)\end{array}$ & $\begin{array}{l}81.1 \\
(1.24)\end{array}$ & $\begin{array}{l}72.3 \\
(2.00)\end{array}$ & $\begin{array}{l}78.8 \\
(1.26)\end{array}$ & $77.6(1.27)$ & $\begin{array}{l}82.2 \\
(0.67)\end{array}$ & $<0.0001$ \\
\hline \multicolumn{9}{|l|}{$\begin{array}{l}\text { Cardiometabolic } \\
\text { factors }^{\wedge}\end{array}$} \\
\hline Hypertension & $6(20.0)$ & $\begin{array}{l}8 \\
(16.7)\end{array}$ & $\begin{array}{l}14 \\
(38.9)\end{array}$ & 0 & $\begin{array}{l}2 \\
(12.5)\end{array}$ & $4(14.3)$ & $\begin{array}{l}14 \\
(41.2)\end{array}$ & 0.001 \\
\hline Hyperglycaemia & $4(13.3)$ & $\begin{array}{l}16 \\
(33.3)\end{array}$ & $\begin{array}{l}18 \\
(50.0)\end{array}$ & $\begin{array}{l}10 \\
(41.7)\end{array}$ & $\begin{array}{l}2 \\
(12.5)\end{array}$ & $6(21.4)$ & $\begin{array}{l}14 \\
(41.2)\end{array}$ & 0.011 \\
\hline Dyslipidaemia & $12(40.0)$ & 22 & 26 & 16 & 6 & $8(28.6)$ & 14 & 0.006 \\
\hline
\end{tabular}




\begin{tabular}{|c|c|c|c|c|c|c|c|c|}
\hline & & $(45.8)$ & $(72.2)$ & (66.7) & (37.5) & & $(41.2)$ & \\
\hline $\begin{array}{l}\text { Metabolic } \\
\text { syndrome }\end{array}$ & $4(13.3)$ & $\begin{array}{l}14 \\
(29.2)\end{array}$ & $\begin{array}{l}10 \\
(27.8)\end{array}$ & $\begin{array}{l}6 \\
(25.0)\end{array}$ & $\begin{array}{l}4 \\
(25.0)\end{array}$ & 0 & $\begin{array}{l}12 \\
(35.3)\end{array}$ & 0.026 \\
\hline
\end{tabular}

Other causes (at least two of ovulatory problems, endometriosis, hyperprolactinemia, tubal factors). Biochemical variables were measured in $\mathrm{mmol} / \mathrm{L}$. All values are presented as mean (standard error of the mean) unless otherwise stated; ${ }^{\wedge}$ represents values presented as frequency (percentage)

The prevalence of hypertension among the study participants was $22.2 \%$. Metabolic syndrome, hyperglycemia and dyslipidemia were presents among $23.1 \%, 32.4 \%$ and $48.1 \%$, respectively [Figure 1].

Figure 2 shows the correlation of anthropometric indices with cardiometabolic risk factors. A significant positive correlation was observed between adiposity indices and fasting plasma glucose except for BAl, which showed no significant correlation ( $p$-value $=0.337)$. A significant positive correlation was observed between $T C$ and $B M I(R=0.37$, $p$-value $<0.0001)$, $W C(R=0.22$, $p$-value $=0.024)$, WHtR $(R=0.19$, $p$-value $=0.044)$ and $A V I(R=0.21, p$-value $=0.030)$. BMI showed a significant positive correlation with TG and LDL, but negative correlation with HDL-C. WC, WHtR and AVI showed a significant positive correlation with LDL-C. Also, all adiposity indices other than WHR showed a significantly positive correlation with systolic blood pressure measurements.

Table 3 shows the criterion of anthropometric measurement for predicting hypertension. Among the indices considered, BMI, WC, WHR, WHtR, and AVI showed significant AUCs indicating their better suitability for predicting MetS, dyslipidemia and hyperglycemia. Also, BAI (AUC=0.721) and BMI (AUC= 0.641) better predict hypertension compared to other adiposity indices. BMI predictive cut-off values among women presenting with primary infertility proved to be the best anthropometric index, as it showed the largest AUC values for MetS (0.731), dyslipidemia (0.707) and hyperglycemia (0.759). Alternative measurements like AVI (AUC=0.749), WC ( $A U C=0.747)$ and WHtR $(A U C=0.742)$ also proved to be better indices for predicting hyperglycemia. Moreover, central obesity indices (WC, WHR, and WHtR) and AVI proved a better alternative index for predicting MetS and dyslipidemia. The cut-off values for predicting MetS were as follows: $W C=90 \mathrm{~cm} ; W H t R=0.61 \mathrm{~cm} / \mathrm{cm} ; \mathrm{BMI}=28.0 \mathrm{~kg} / \mathrm{m}^{2} ; \mathrm{WHR}=0.89$ and $\mathrm{AVl}=16.5$ units.

Table 3: Criterion of anthropometric measurements for predicting cardiometabolic risk factors among primary infertility patients 


\begin{tabular}{|lllllll|}
\hline Variable & BMI & WC & WHR & WHtR & BAl & AVI \\
\hline Mets & & & & & & \\
AUC & $\mathbf{0 . 7 3 1}$ & $\mathbf{0 . 6 9 0}$ & $\mathbf{0 . 6 5 3}$ & $\mathbf{0 . 6 6 9}$ & 0.595 & $\mathbf{0 . 6 8 8}$ \\
Sensitivity & 0.760 & 0.680 & 0.640 & 0.400 & 0.398 & 0.680 \\
\hline Specificity & 0.614 & 0.675 & 0.687 & 0.928 & 0.840 & 0.675 \\
\hline Criterion & $>28.0$ & $>90.0$ & $>0.89$ & $>0.61$ & $>29.9$ & $>16.5$ \\
\hline Dyslipidaemia & & & & & & \\
\hline AUC & $\mathbf{0 . 7 0 7}$ & $\mathbf{0 . 6 2 7}$ & $\mathbf{0 . 6 5 0}$ & $\mathbf{0 . 6 1 4}$ & 0.541 & $\mathbf{0 . 6 2 2}$ \\
\hline Sensitivity & 0.654 & 0.692 & 0.712 & 0.750 & 0.788 & 0.712 \\
\hline Specificity & 0.714 & 0.517 & 0.589 & 0.446 & 0.375 & 0.500 \\
\hline Criterion & $>28.0$ & $>84.0$ & $>0.85$ & $>0.52$ & $>29.4$ & $>14.3$ \\
\hline Hyperglycaemia & & & & & & \\
\hline AUC & $\mathbf{0 . 7 5 9}$ & $\mathbf{0 . 7 4 7}$ & $\mathbf{0 . 6 7 5}$ & $\mathbf{0 . 7 4 2}$ & $\mathbf{0 . 6 6 6}$ & $\mathbf{0 . 7 4 9}$ \\
\hline Sensitivity & 0.914 & 0.743 & 0.629 & 0.686 & 0.686 & 0.771 \\
\hline Specificity & 0.534 & 0.671 & 0.726 & 0.726 & 0.630 & 0.671 \\
\hline Criterion & $>25.8$ & $>88.0$ & $>0.89$ & $>0.57$ & $>32.1$ & $>15.6$ \\
\hline Hypertension & & & & & & \\
\hline AUC & $\mathbf{0 . 6 4 1}$ & 0.565 & 0.437 & 0.592 & $\mathbf{0 . 7 2 1}$ & 0.570 \\
\hline Sensitivity & 0.500 & 0.417 & 0.333 & 0.583 & 0.875 & 0.417 \\
\hline Specificity & 0.810 & 0.738 & 0.604 & 0.595 & 0.548 & 0.750 \\
\hline Criterion & $>33.2$ & $>95.0$ & $>0.90$ & $>0.56$ & $>31.3$ & $>18.4$ \\
\hline
\end{tabular}

AUC- area under the curve. All values highlighted represent statistically significant variables.

Table 4 shows the logistic regression analysis of various anthropometric cut-off values predictive of cardiometabolic factors. The odds ratios (95\% confidence interval) for BMI, WC, WHR, WHtR and AVI were 4.96 (2.36-10.40), 4.56 (2.249.26), 5.35 (2.53-11.31), 7.45 (3.24-17.10) and 4.56 (2.24-9.26), respectively for predicting MetS. However, in the multivariate model, WC and AVI were no longer significant in predicting MetS. The odds ratios for predicting dyslipidemia was significant for BMI, WC, WHR, WHtR, and AVI in the univariate-adjusted model. However, in the multivariate model, only BMI and WHR were significant for predicting dyslipidemia. BMI (OR=7.52), WHR (OR=5.71) and $\mathrm{BAI}(\mathrm{OR}=3.49)$ proved to be the most significant adiposity indices for predicting hyperglycemia.

Table 4: Logistic regression analysis of various anthropometric cut-off values predictive of cardiometabolic factors 


\begin{tabular}{|c|c|c|c|c|c|}
\hline Variable & $\begin{array}{l}\text { Univariate-adjusted } \\
\text { OR }(95 \% \mathrm{Cl})\end{array}$ & P-value & $\begin{array}{l}\text { Multivariate } \\
\text { OR }(95 \% \mathrm{Cl})\end{array}$ & P-value & Kappa \\
\hline \multicolumn{6}{|l|}{ Mets } \\
\hline BMI & $4.96(2.36-10.40)$ & $<0.0001$ & 3.35 (1.41-7.93) & 0.006 & 0.263 \\
\hline WC & $4.56(2.24-9.26)$ & $<0.0001$ & $0.95(0.36-2.48)$ & 0.917 & 0.280 \\
\hline WHR & $5.35(2.53-11.31)$ & $<0.0001$ & $2.77(1.29-5.93)$ & 0.009 & 0.264 \\
\hline WHtR & 7.45 (3.24-17.10) & $<0.0001$ & $4.88(1.81-13.21)$ & 0.002 & 0.375 \\
\hline AVI & $4.56(2.24-9.26)$ & $<0.0001$ & - & - & 0.280 \\
\hline \multicolumn{6}{|c|}{ Dyslipidaemia } \\
\hline BMI & $3.71(2.00-6.86)$ & $<0.0001$ & 3.98 (2.03-7.79) & $<0.0001$ & 0.332 \\
\hline WC & $2.66(1.45-4.86)$ & 0.002 & $0.23(0.02-2.61)$ & 0.237 & 0.209 \\
\hline WHR & $2.77(1.51-5.07)$ & 0.001 & $3.47(1.81-6.65)$ & $<0.0001$ & 0.299 \\
\hline WHtR & $2.43(1.30-4.52)$ & 0.005 & $0.92(0.26-3.29)$ & 0.903 & 0.194 \\
\hline AVI & $2.97(1.61-5.47)$ & $<0.0001$ & $3.96(0.51-30.75)$ & 0.189 & 0.210 \\
\hline \multicolumn{6}{|c|}{ Hyperglycaemia } \\
\hline BMI & $13.43(5.26-34.30)$ & $<0.0001$ & $7.52(2.69-21.02)$ & $<0.0001$ & 0.365 \\
\hline WC & $5.61(2.87-10.94)$ & $<0.0001$ & $0.19(0.02-1.63)$ & 0.129 & 0.373 \\
\hline WHR & $4.05(2.13-7.71)$ & $<0.0001$ & $5.71(2.33-14.00)$ & $<0.001$ & 0.337 \\
\hline WHtR & $5.72(2.93-11.16)$ & $<0.0001$ & $1.28(0.45-3.66)$ & 0.650 & 0.386 \\
\hline BAI & $4.32(2.20-8.49)$ & $<0.0001$ & $3.49(1.42-8.56)$ & 0.006 & 0.258 \\
\hline AVI & $5.67(2.86-11.22)$ & $<0.0001$ & $4.34(0.60-31.64)$ & 0.147 & 0.366 \\
\hline \multicolumn{6}{|c|}{ Hypertension } \\
\hline BMI & $4.15(2.07-8.33)$ & $<0.0001$ & $2.47(1.19-5.13)$ & 0.016 & 0.292 \\
\hline BAI & $8.52(3.40-21.34)$ & $<0.0001$ & $6.35(2.48-16.28)$ & $<0.0001$ & 0.278 \\
\hline
\end{tabular}

Univariate-adjusted (adjusted for age, duration of infertility, causes of infertility). OR-odds ratios; Cl-confidence interval. Values highlighted in back denotes statistically significant variables

\section{Discussion}

Cardiovascular risk factors are common symptoms associated with women with infertility [29]. We observed the prevalence of hypertension, hyperglycemia, dyslipidemia and MetS of $22.2 \%, 23.1 \%, 32.4 \%$, and $48.1 \%$, respectively among women with primary infertility. The common cardiovascular risk symptoms including dyslipidemia, hyperglycemia, hypertension and metabolic syndrome among infertile women have been thought to be mediated by pathways based on the aetiology of infertility [28]. Previous studies by Valkenburg et al., [30] and Zhang et al., [31] has reported a high prevalence of dyslipidemia among infertile women with the polycystic ovarian syndrome as the 
underlying cause. Also, worse cardiometabolic risk profile among infertile women with hyperandrogenic phenotypes have been documented [32]. Our finding showed that women with hyperprolactinemia, uterine and unexplained cause of infertility were less likely to present with hypertension, hyperglycemia and dyslipidemia [Supplementary Table 2]. However, a malefactor associated infertility; infertile women with at least two of the following, ovulatory problems, endometriosis, hyperprolactinemia, tubal factors as well as infertile women with PCOS as the underlying cause was associated with increased likelihood cardiometabolic risk factors. Thus, our findings in line with previous findings, present a picture of a high prevalence of cardiometabolic risk factors among women with infertility which is largely dependent on the aetiology of infertility, and factors including hyperandrogenism and obesity-associated as predisposing factors [33]. Pasquali [34] in a study reported that hormonal alterations among infertile women may play an important role in the pathophysiology of obesity and its associated metabolic and cardiovascular comorbidities.

Consistent with literature [31, 32], our study demonstrated that adiposity indices are associated with cardiometabolic risk factors with stronger associations observed for the index that reflects general adiposity (i.e., BMI). Additionally, central adiposity indices (WC, WHR, and WHtR) proved stronger in predicting MetS, dyslipidemia and hyperglycemia. Consistent with our findings, studies evaluating cardiovascular risk factors among infertile women have consistently reported BMI and WC as the strongest predictor [29,33]. In a study by Gadelha et al., [35] comparing adiposity indices for predicting MetS among postmenopausal women reported that central adiposity indices such as WC and WHtR strongly predict MetS, which is partly consistent with our present finding. In a study among women of different socioeconomic class, BMI was reported as the best indicator for predicting metabolic abnormalities [36]. Gowda and Philip [36] indicated that indices like AVI and WC could be used along with BMI in the prediction of multiple metabolic abnormalities, which is consistent with our findings. Although the observations of this study are partly comparable with previous reports, it is important to note that infertile women show characteristic differences in body composition and fat distribution patterns when compared with healthy, fertile, age-matched counterparts [37].

There is a paucity of cut-off values in the literature regarding the determination of cardiometabolic risk factors among women with primary infertility. Thus, our study was designed to better define cardiometabolic risk factors in a sample of women with primary infertility from Ghana. Although several studies have been conducted to evaluate optimal cutoff values of adiposity indices for predicting cardiometabolic risk factors among women [35, 36], results specifically for women presenting with primary infertility, whose body composition and fat distribution patterns differ when compared with healthy, fertile, age-matched counterparts [37] remain to be defined. The best predictive cut-off values for $\mathrm{BMI}\left(>25.8 \mathrm{Kg} / \mathrm{m}^{2}\right.$ and $\left.>28.0 \mathrm{Kg} / \mathrm{m}^{2}\right)$, strongly predicted hyperglycemia, MetS, and dyslipidemia. Additionally, the range of optimal cut-off values of central obesity indices including WC $(84.0 \mathrm{~cm}-90.0 \mathrm{~cm})$, WHR $(0.85-0.89 \mathrm{~cm} / \mathrm{cm})$, WHtR $(0.52-0.61 \mathrm{~cm} / \mathrm{cm})$ as well as AVI (14.3 to 16.5) which consider regional fat distribution and are better reflections of vascular anatomy and metabolic activity [38], better predicted MetS, dyslipidaemia and hyperglycaemia. The criterion for WHtR (>0.61) was associated with the highest odds and better agreement for predicting MetS, possibly because it reflects the ratio between WC and height. Thus reducing the chances of overestimating or underestimating central obesity, similar to findings by Gadelha et al., [35] among postmenopausal women.

The limitation of the study is its cross-sectional design which precludes cause-effect inferences. Furthermore, the number of volunteers participating in the study and the sample frame was relatively small; even though the sample size calculation was designed to represent infertile women in Ghana. Thus, it may not be representative of the whole country of Ghana since the study was localized at the Komfo Anokye Teaching Hospital. Also, there was a lack of national cut-off data on adiposity indices currently used in Ghana for women other than the one established by the World Health Organization [39]. However, our findings suggest that to predict and define intervention strategies for cardiometabolic risk among women with primary infertility, the criterion for defining overweight/obesity in this study could be useful for weight-control programs. 


\section{Conclusion}

Consistent with the literature, cardiometabolic risk factors including hypertension, hyperglycemia, dyslipidemia and MetS is high among women with primary infertility. Various adiposity indices are associated with cardiometabolic risk factors in primary infertile women

\section{Declarations}

\section{Funding}

No funding was obtained for the study

\section{Competing Interests}

The authors declare that they have no competing interests

\section{Ethical Statement}

This study was approved by the Manhyia Government Hospital Kumasi. All patients enrolling in the study completed a written informed consent form following the Helsinki Declaration.

\section{Consent for Publication}

Not applicable

\section{Acknowledgements}

The Authors acknowledge the hard work of the Staff of Manhyia Government Hospital, in their effortless contribution to the success of this study

\section{Availability of Data}

The datasets used and analyzed during the study are available from the corresponding author on reasonable request

\section{References}

1. Inhorn MC. Global infertility and the globalization of new reproductive technologies: illustrations from Egypt. Social science \& medicine. 2003;56(9):1837-51.

2. Ombelet W. Global access to infertility care in developing countries: a case of human rights, equity and social justice. Facts, views \& vision in ObGyn. 2011;3(4):257.

3. Nachtigall RD. International disparities in access to infertility services. Fertility and sterility. 2006;85(4):871-5.

4. Mascarenhas MN, Flaxman SR, Boerma T, Vanderpoel S, Stevens GA. National, regional, and global trends in infertility prevalence since 1990: a systematic analysis of 277 health surveys. PLoS medicine. 2012;9(12):e1001356.

5. Geelhoed D, Nayembil D, Asare K, Schagen van Leeuwen J, Van Roosmalen J. Infertility in rural Ghana. International Journal of Gynecology \& Obstetrics. 2002;79(2):137-42.

6. Tabong PT-N, Adongo PB. Infertility and childlessness: a qualitative study of the experiences of infertile couples in Northern Ghana. BMC pregnancy and childbirth. 2013;13(1):72. 
7. Andrews FM, Abbey A, Halman LJ. Stress from infertility, marriage factors, and subjective well-being of wives and husbands. Journal of health and social behavior. 1991:238-53.

8. Verit FF, Yildiz Zeyrek F, Zebitay AG, Akyol H. Cardiovascular risk may be increased in women with unexplained infertility. Clin Exp Reprod Med. 2017;44(1):28-32.

9. Parikh NI, Cnattingius S, Mittleman MA, Ludvigsson JF, Ingelsson EJHr. Subfertility and risk of later life maternal cardiovascular disease. 2011;27(2):568-75.

10. Agarwal A, Aponte-Mellado A, Premkumar BJ, Shaman A, Gupta SJRb, endocrinology. The effects of oxidative stress on female reproduction: a review. 2012;10(1):49.

11. Rogers J, Mitchell Jr GWJNEJoM. The relation of obesity to menstrual disturbances. 1952;247(2):53-5.

12. Hartz A, Barboriak PN, Wong A, Katayama KP, Rimm AAJljoo. The association of obesity with infertility and related menstural abnormalities in women. 1979;3(1):57-73.

13. Cetin I, Cozzi V, Antonazzo P. Infertility as a cancer risk factor-a review. Placenta. 2008;29:169-77.

14. Silvestris E, de Pergola G, Rosania R, Loverro G. Obesity as disruptor of the female fertility. Reprod Biol Endocrinol. 2018;16(1):22-.

15. Dağ ZÖ, Dilbaz B. Impact of obesity on infertility in women. J Turk Ger Gynecol Assoc. 2015;16(2):111-7.

16. Wild S, Pierpoint T, McKeigue P, Jacobs HJCe. Cardiovascular disease in women with polycystic ovary syndrome at long-term follow-up: a retrospective cohort study. 2000;52(5):595-600.

17. Gutiérrez C, Lozano-Hernández R, Lozano C-A, Villavicencio AJRdOyGdV. Tensión arterial y masa corporal en mujeres infértiles con síndrome de ovario poliquístico y su relación con el perfil hormonal. 2014;74(3):170-6.

18. Park Y-W, Zhu S, Palaniappan L, Heshka S, Carnethon MR, Heymsfield SB. The metabolic syndrome: prevalence and associated risk factor findings in the US population from the Third National Health and Nutrition Examination Survey, 1988-1994. Archives of internal medicine. 2003;163(4):427-36.

19. Prinsloo J, Malan L, De Ridder J, Potgieter J, Steyn H. Determining the waist circumference cut off which best predicts the metabolic syndrome components in urban Africans: the SABPA study. Experimental and clinical endocrinology \& diabetes. 2011;119(10):599-603.

20. Hu FB. Measurements of adiposity and body composition. Obesity epidemiology. 2008;53:83.

21. Wells J, Fewtrell M. Measuring body composition. Archives of disease in childhood. 2006;91(7):612-7.

22. Peltz G, Aguirre MT, Sanderson M, Fadden MK. The role of fat mass index in determining obesity. American Journal of Human Biology. 2010;22(5):639-47.

23. Kim CH. Measurements of Adiposity and Body Composition. The Korean Journal of Obesity. 2016;25(3):115-20.

24. Cochran WG. Sampling techniques: John Wiley \& Sons; 2007.

25. Guerrero-Romero F, Rodríguez-Morán M. Abdominal volume index. An anthropometry-based index for estimation of obesity is strongly related to impaired glucose tolerance and type 2 diabetes mellitus. Archives of medical research. 2003;34(5):428-32.

26. Freedman DS, Thornton JC, Pi-Sunyer FX, Heymsfield SB, Wang J, Pierson Jr RN, et al. The body adiposity index (hip circumference $\div$ height1. 5) is not a more accurate measure of adiposity than is BMI, waist circumference, or hip circumference. Obesity. 2012;20(12):2438-44.

27. Expert Panel on Detection E. Executive summary of the third report of the National Cholesterol Education Program (NCEP) expert panel on detection, evaluation, and treatment of high blood cholesterol in adults (Adult Treatment Panel III). Jama. 2001;285(19):2486. 
28. Zhang ZQ, Liu YH, Xu Y, Dai XW, Ling Wh, Su YX, et al. The validity of the body adiposity index in predicting percentage body fat and cardiovascular risk factors among C hinese. Clinical endocrinology. 2014;81(3):356-62.

29. Mahalingaiah S, Sun F, Cheng JJ, Chow ET, Lunetta KL, Murabito JM. Cardiovascular risk factors among women with self-reported infertility. Fertil Res Pract. 2017;3:7-.

30. Valkenburg O, Steegers-Theunissen RP, Smedts HP, Dallinga-Thie GM, Fauser BC, Westerveld EH, et al. A more atherogenic serum lipoprotein profile is present in women with polycystic ovary syndrome: a case-control study. The Journal Of Clinical Endocrinology \& Metabolism. 2008;93(2):470-6.

31. Zhang J, Fan P, Liu H, Bai H, Wang Y, Zhang F. Apolipoprotein Al and B levels, dyslipidemia and metabolic syndrome in south-west Chinese women with PCOS. Human reproduction. 2012;27(8):2484-93.

32. Daan NM, Louwers YV, Koster MP, Eijkemans MJ, de Rijke YB, Lentjes EW, et al. Cardiovascular and metabolic profiles amongst different polycystic ovary syndrome phenotypes: who is really at risk? Fertility and sterility. 2014;102(5):1444-51. e3.

33. Rizzo M, Rizvi AA, Rini GB, Berneis K. The therapeutic modulation of atherogenic dyslipidemia and inflammatory markers in the metabolic syndrome: what is the clinical relevance? Acta diabetologica. 2009;46(1):1-11.

34. Pasquali R. Obesity, fat distribution and infertility. Maturitas. 2006;54(4):363-71.

35. Gadelha AB, Myers J, Moreira S, Dutra MT, Safons MP, Lima RM. Comparison of adiposity indices and cut-off values in the prediction of metabolic syndrome in postmenopausal women. Diabetes \& Metabolic Syndrome: Clinical Research \& Reviews. 2016;10(3):143-8.

36. Gowda V, Philip K. Abdominal volume index and conicity index in predicting metabolic abnormalities in young women of different socioeconomic class. Int J Med Sci Public Health. 2016;5(7):1452-6.

37. Kirchengast S, Huber J. Body composition characteristics and fat distribution patterns in young infertile women. Fertility and sterility. 2004;81(3):539-44.

38. Menke A, Muntner P, Wildman RP, Reynolds K, He J. Measures of adiposity and cardiovascular disease risk factors. Obesity. 2007;15(3):785-95.

39. Organization WH. Waist circumference and waist-hip ratio: report of a WHO expert consultation, Geneva, 8-11 December 2008. 2011.

\section{Figures}




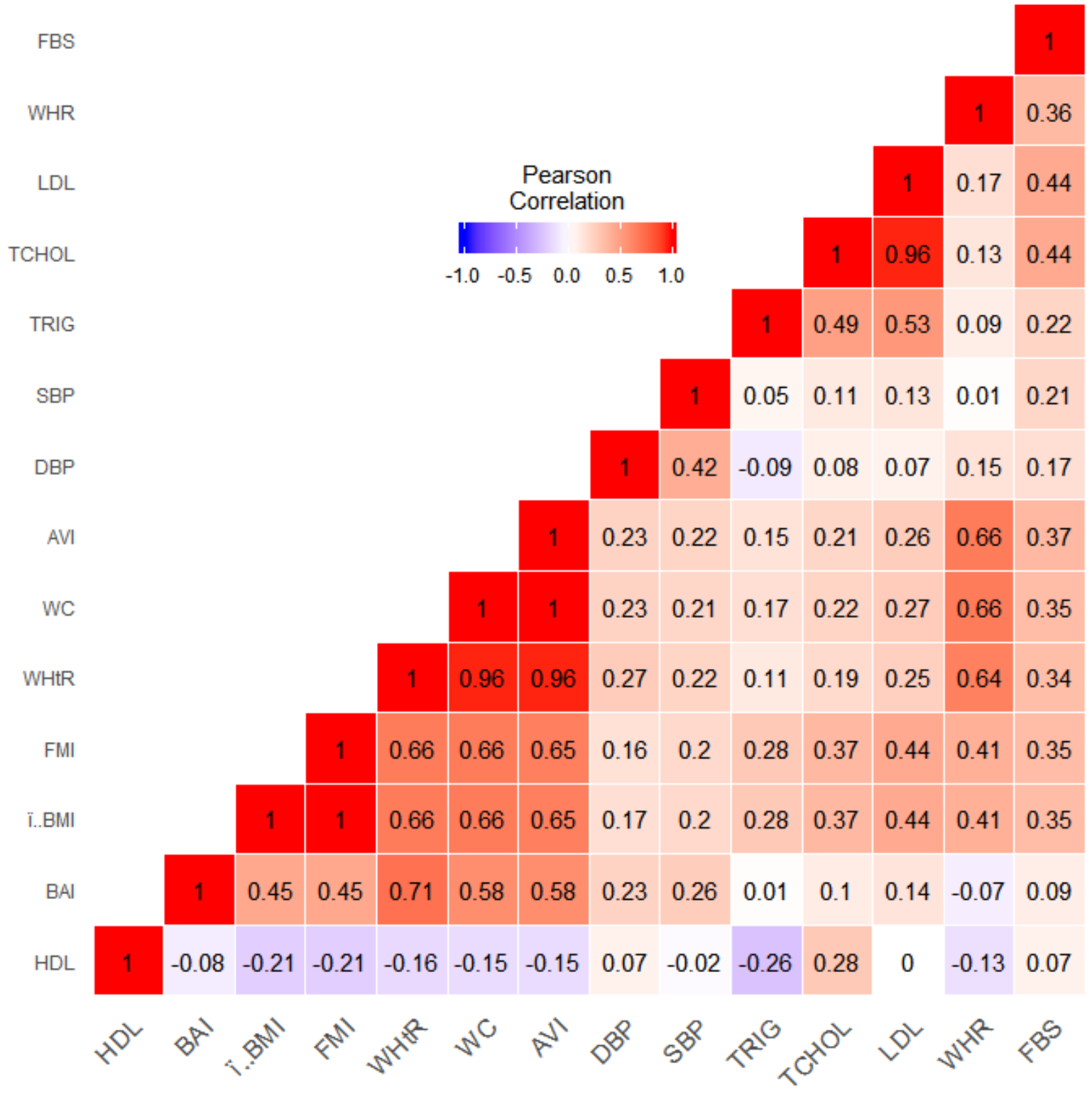

Figure 1

Prevalence of cardiometabolic factors among women with primary infertility 


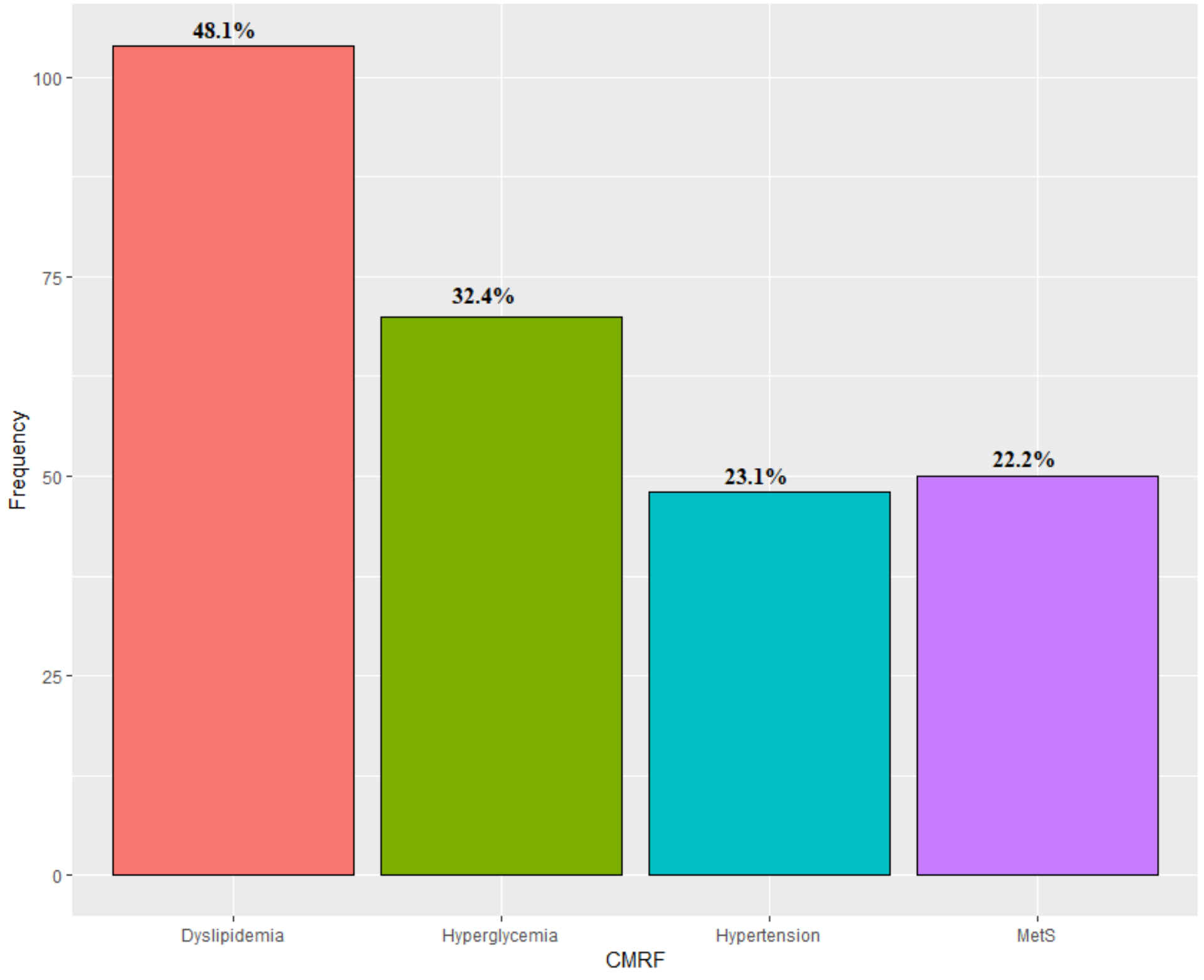

Figure 2

Correlation between anthropometric indices and cardiometabolic risk factors

\section{Supplementary Files}

This is a list of supplementary files associated with this preprint. Click to download.

- Supplemetarymaterial.docx 